\title{
Gut microbiota changes in airway diseases: a systematic review
}

\author{
Alterações da microbiota intestinal em doenças das vias aéreas: uma revisão \\ sistemática
}

Fabine Correia Passos ${ }^{1}$, Lucas Matheus Gonçalves de Oliveira², Odilon Lobão Leal Neto ${ }^{3}$, Fabíola Ramos Jesus ${ }^{4}$, Michelle Miranda Lopes Falcão ${ }^{5}$, Margarida Célia Lima Costa Neves ${ }^{6}$, Antônio Carlos Moreira Lemos $^{7}$, Gyselle Chrystina Baccan ${ }^{8 *}$

\begin{abstract}
${ }^{1}$ Mestre em Alimentos, Nutrição e Saúde; ${ }^{2}$ Mestre em Bioquímica e Biologia Molecular pela Sociedade Brasileira de Bioquímica e Biologia Molecular; ${ }^{3}$ Graduado em Nutrição; ${ }^{4}$ Mestre em Imunologia; ${ }^{5}$ Doutora em Imunologia; ${ }^{6}$ Doutora em Medicina e Saúde, professora adjunto, UFBA; 'Doutor em Medicina e Saúde, Brazil, professor Associado, UFBA; ${ }^{8}$ Doutora em Bioquímica, Professor Associado UFBA
\end{abstract}

\begin{abstract}
Introduction: studies have highlighted the importance of gut microbiota (GM) to the host immune defenses, influencing the host development and physiology. Changes in the composition and diversity of GM have been detected in some disease and could be implicated in the pathophysiological mechanisms of them. Objective: the purpose of this study was to show an overview of the current knowledge about the GM of patients with airway diseases (AD). Methodology: the literature search was performed in four databases, using a combination of the descriptors: "Gastrointestinal Microbiome", "Gut Microbiome", "Gut Microbiota", "Cystic Fibrosis" (CF), "Asthma", "Pulmonary Hypertension" (HP) and/or "Chronic Obstructive Pulmonary Disease" (COPD). Results: fifteen studies were herein included: ten of CF and five of asthma. No study about other AD matched the inclusion criteria. In all studies about CF, changes were detected in GM, particularly quantitative and qualitative microbial changes. For asthma, data showed changes in GM also including a reduction of microbial richness, evenness and diversity and in the Bacteroidetes/Firmicutes ratio. Conclusions: the current data indicate the existence of GM changes in $A D$. However, due to the few studies for asthma and the lack of investigations on HP and COPD, it was not possible to confirm whether these GM changes are observed in other AD. Furthermore, this review shows the necessity of more studies in this area to characterize dysbiosis and which alterations are more frequent observed in $A D$ patients. Keywords: Gut Microbiota. Airway Diseases. Cystic Fibrosis. Asthma. Pulmonary Hypertension. Chronic Obstructive Pulmonary Disease.
\end{abstract}

\begin{abstract}
Resumo
Introdução: estudos têm destacado a importância da microbiota intestinal (GM) para as defesas imunológicas do hospedeiro, influenciando o desenvolvimento e a fisiologia do hospedeiro. Mudanças na composição e diversidade da GM foram detectadas em algumas doenças e podem estar implicadas nos mecanismos fisiopatológicos delas. Objetivo: o objetivo desta revisão foi avaliar estudos sobre a microbiota intestinal (MI) de pacientes com doenças das vias aéreas (DA). Metodologia: esta pesquisa bibliográfica foi realizada em quatro bases de dados, utilizando a combinação dos descritores: "Microbioma Gastrointestinal”, "Microbioma Intestinal”, “Microbiota Intestinal”, "Fibrose Cística” (CF), "Asma”, "Hipertensão Pulmonar” (HP), "Doença Pulmonar Obstrutiva Crônica” (DPOC). Resultados: quinze estudos foram incluídos: dez de FC e cinco de asma. Nenhum estudo sobre outra DA correspondeu aos critérios de inclusão. Em todos os estudos sobre FC, foram detectadas alterações na MI, particularmente alterações microbianas qualitativas e quantitativas. Para a asma, os dados mostraram mudanças na MI, incluindo também uma redução da quantidade, uniformidade e diversidade microbiana e na razão Bacteroidetes/Firmicutes. Conclusão: os dados atuais indicam a existência de alterações na MI nas DA. No entanto, devido aos poucos estudos para asma e à falta de investigações para HP e DPOC, não foi possível confirmar se essas alterações na MI são observadas em outras DA também. Além disso, esta revisão mostra a necessidade de mais estudos nessa área para caracterizar a disbiose e quais alterações são mais frequentes em pacientes com DA.

Palavras-chave: Microbiota Intestinal. Doenças das Vias Aéreas. Fibrose Cística. Asma. Hipertensão Pulmonar. Doença Pulmonar Obstrutiva Crônica.
\end{abstract}

\section{INTRODUCTION}

Human gut microbiota (GM) has been extensively studied in recent years and has been recognized as a key player in the regulation of immune system ${ }^{1}$. These studies have evidenced the presence of dysbiosis in some pathol-

Correspondente/Correponding: *Gyselle Chrystina Baccan - Departamento de Bioquímica e Biofísica, Instituto de Ciências da Saúde, Universidade Federal da Bahia - End.: Av. Reitor Miguel Calmon s/n, Vale do Canela, Salvador-Ba - Tel: (71) 3283-8914 - E-mail: gbaccan@ufba.br ogies and have discussed the importance of these GM changes in the development and outcome of diseases ${ }^{2}$.

In this context, evidences have indicated the existence of the complex relationships between GM and the lung, with implications for both lung and intestinal diseases ${ }^{3}$. Airway diseases $(A D)$ are characterized by some changes in pulmonary function, usually with chronic inflammation, impairment of the life quality, without effective treatments that lead to the cure. In this group are cystic fibrosis (CF), asthma, pulmonary hypertension (PH) and chronic ob- 
structive pulmonary disease (COPD). Mechanisms through which GM could influence the lung immune responses are not well understood, but some evidences point to a crosstalk between these organs, which is mediated by GM, specially through toll-like receptors (TLR) signaling and cellular homing ${ }^{4}$.

The aim of this systematic review was to show an overview of the current knowledge about the GM changes in the main ADs, to evaluate whether there is dysbiosis and to determine what are the main alterations observed in these diseases.

\section{METHODS}

This systematic review was performed according to the PICOS (Patient, Intervention, Comparators, Outcome, Study) design protocol structure, used to develop the main question as well as inclusion and exclusion criteria. Our team searched for articles where the GM of healthy individuals (HI) was compared with the GM of patients with specific $A D$ (CF, asthma, $P H$ and COPD), published from 2008 to December 2018. The search was made in four (4) electronic databases (MEDLINE/LILACS, PubMed, ScienceDirect and Scopus), using combination of descriptors from The Medical Subjective Headings (MeSH) and Health Sciences Descriptors (DeCS). The descriptors utilized in all platforms were "Gastrointestinal Microbiome", "Gut Microbiome", "Gut Microbiota", "Asthma", "Cystic Fibrosis", "Pulmonary Hypertension", "Chronic Obstructive Pulmonary Disease" in combination with Boolean operators (OR, AND, NOT).

We included in this review only original observational studies which were designed to examine the qualitative and quantitative changes of the GM in the target population. No restriction was applied regarding language, age, gender, level and duration of disease. Two authors performed independently the research. Discrepancies in the article election/exclusion were resolved by discussion involving consultation with a third expert subject until the consensus of all authors. Furthermore, manual research was made in the reference list of the relevant articles to enable a further inclusion in our review, without any bias towards author or journal. Details of the systematic review were registered (CRD42018103438) in the PROSPERO International Prospective Register of Systematic Reviews.

\section{RESULTS}

In the electronic search conducted in the databases, it was found 1912 articles. 1101 duplicated articles were excluded. After the analysis of titles and/or abstracts, 64 articles were selected. Only 15 articles met the inclusion criteria of this review (fig 1).

Regarding the studies comparing GM from individuals with CF and their HI, we found 363 articles. Of these articles, 211 were duplicated studies. After reading titles and/ or abstracts only 28 were selected. Outcomes of interest were identified in ten articles (fig 1).

About asthma, we initially found 1341 articles that compared the GM of patients with $\mathrm{Hl}$; of these, 789 were excluded because they were duplicates. After performing the analysis of titles and/or abstracts, 32 were screened. Only five articles presented all inclusion criteria (fig 1).

About the systematic search using the descriptors for $\mathrm{PH}, 35$ articles were found and 12 duplicated articles were excluded. No articles compared the GM of the individuals with $\mathrm{PH}$ and $\mathrm{HI}$ (fig 1).

In the systematic search for COPD, it were used the additional descriptors "pulmonary emphysema" and "bronchitis", although these expressions are no longer used to define COPD. For PE, only two articles were found, and none of them addressed the outcomes of interest (fig 1). About the systematic search using the descriptors for Bronchitis, 40 articles were found and 15 articles were duplicates and excluded. After the reading of the titles and/or abstracts, 21 were excluded. After reading the complete text, all manuscripts were excluded because they did not meet the inclusion criteria (fig 1). In the systematic search using the descriptors "chronic obstructive pulmonary disease", 131 articles were found. After reading the titles and/or abstracts of the remaining, no articles were found that addressed the outcomes of interest (fig 1).

\section{Major GM changes in airway diseases}

The overall studies found alterations in the GM; however the taxonomic groups differed among the articles (Table 1). The data showed evidence of reduction of the microbial richness and/or diversity in CF patients ${ }^{5-9}$. Only three studies associated the GM species diversity with the age, two of them showed reduction of the species diversity with the increase in age 7,8. Despite the few studies about GM and asthma, the results indicate some alterations. Only one study evaluated the species diversity in asthma patients ${ }^{10}$. A reduction of the microbial richness and diversity with no changes in alpha-diversity was described in one study ${ }^{10}$.

The main phyla evaluated in articles were Firmicutes, Bacteroidetes and Actinobacteria. Regarding the $\mathrm{CF}$, the increase in the relative abundance of Firmicutes was detected in two studies ${ }^{9,11}$. On the other hand, two other studies described a decrease in this phylum ${ }^{8,12}$. A reduction of the abundance of Bacteroidetes was detected in three studies $8,9,11$ and an increase in this phylum was observed in one study ${ }^{12}$. Only two studies showed reduction of the levels of Bacteroides in asthma patients ${ }^{10,13}$, also a reduction of Bacteroidetes/Firmicutes ratio in one study on asthma ${ }^{13}$.

Regarding CF, studies have showed a decrease in the beneficial intestinal bacteria that could be considered markers of gut health. In two studies with the genus Roseburia, there was a decrease in those bacteria ${ }^{9,12}$. In four studies, the authors found a reduced level of Faecalibacterium prausnitzii ${ }^{5,9,11,12}$. The data showed one study describing the reduction of F. prausnitzii in asthma [10] and other one showed increase ${ }^{14}$.

Regarding the Actinobacteria, it was found a reduction in two studies ${ }^{11,12}$ and other two articles found an increase 
in the levels of this phylum in CF patients ${ }^{8,9}$. Low levels of Bifidobacterium spp. were detected by many authors ${ }^{5,6,9,11-}$ 16. Only one study found that the order Lactobacillales was significantly enriched in CF patients. Regarding asthma, a reduction in the levels of Bifidobacterium ${ }^{17}, B$. longum, $B$. breve and $B$. bifidum ${ }^{11}$, and increase level of Bifidobacterium $^{13}, B$. adolescentis was detected ${ }^{14}$. This genus was negatively correlated with the disease duration and positively with the IgE levels in asthma patients ${ }^{14}$. Regarding Lactobacillus, one study identified higher levels of this genus in asthma patients ${ }^{17}$, but other showed a reduction of these bacteria ${ }^{18}$.

Regarding CF, an increase in the level of Proteobacteria was observed in some studies ${ }^{8,12}$ while a reduction was described by others authors ${ }^{9,11}$. The increased abundance of Escherichia coli was found in two studies that assessed the GM of children ${ }^{8,19}$. In contrast, in one study, authors detected a reduction in the levels of this bacterial species
5. In asthma patient only one study identified higher levels of the $E$. coli ${ }^{18}$. A reduction in the abundance of Clostridium clusters XIVa ${ }^{15}$ and of $\mathrm{Cl}$. coccoides ${ }^{5}$. Other studies observed an increase in the level of the, Cl. difficile [8], $\mathrm{Cl}$. clostridioforme and Cl. nexile ${ }^{12}$ in CF patient. But a reduction in the abundance of $\mathrm{Cl}$. leptum sub group was showed in asthma patients ${ }^{17}$.

The relationship of the GM composition and the lung function was evaluated only in three articles for CF. The forced expiratory volume in $1 s\left(F E V_{1}\right)^{5}$ and the forced vital capacity (FCV) ${ }^{15}$ did not show any correlation with the GM composition. One article showed positive relation between FEV and GM diversity ${ }^{9}$. When studying the GM of children with $C F$, it was observed that the alteration in GM leads to changes in functional capacities of the microbiome ${ }^{8}$. Metabolomic analyses suggests that the changes in the GM could be involved with pathways of unsaturated fatty acids biosynthesis and xenobiotic metabolism ${ }^{11}$.

Figure 1 - Flowchart of identification and selection of articles about composition of GM of patients with Asthma, CF, HP, PE, Bronchitis and COPD.

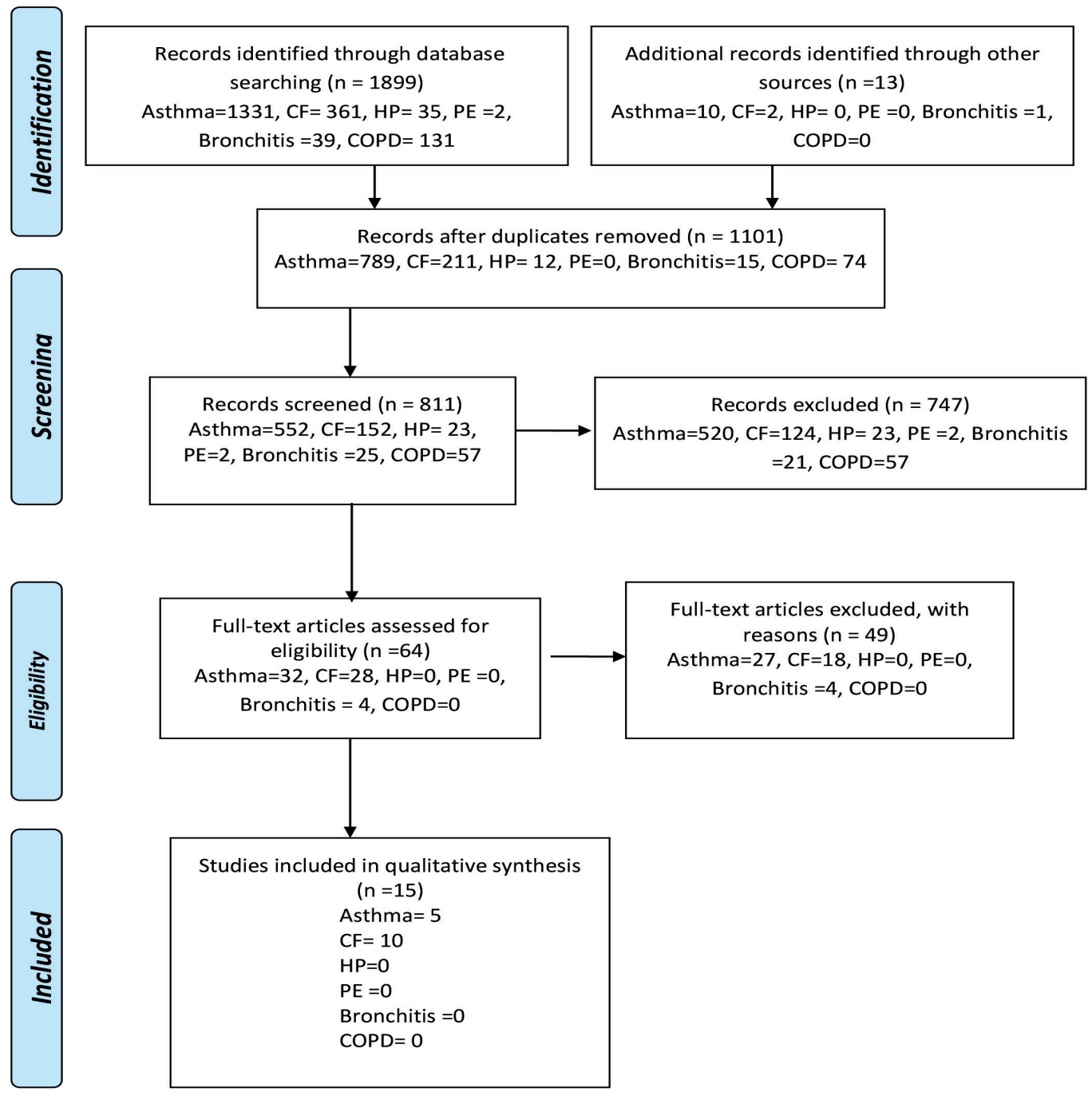

Fonte: Autoria própria 
Table 1 - Studies about gut microbiota changes and airway diseases.

\begin{tabular}{|c|c|c|c|c|c|}
\hline Reference & Disease & Sample size & Age range & $\begin{array}{l}\text { Technique for } \\
\text { Analysis }\end{array}$ & Results: patients compared with healthy individuals \\
\hline $\begin{array}{l}\text { Burke et al. } \\
2017^{9}\end{array}$ & $\begin{array}{l}\text { Cystic } \\
\text { Fibrosis }\end{array}$ & $\begin{array}{l}43 \text { patients } \\
69 \mathrm{HI}\end{array}$ & $21-40$ years & $N_{G S}^{a}$ & $\begin{array}{l}\downarrow \text { Bacteroidetes, Proteobacteria, Cyanobacteria and Verruco- } \\
\text { microbia } \\
\uparrow \text { Firmicutes and Actinobacteria } \\
\downarrow \text { Alcaligenaceae, Prevotellaceae, Bifidobacteriaceae and Pep- } \\
\text { tococcaceae } \\
\uparrow \text { Enterococcus, Bacteroides, Leuconosto } \\
\downarrow \text { Roseburia, Prevotella, Odoribacter, Faecalibacterium and } \\
\text { Bifidobacterium }\end{array}$ \\
\hline $\begin{array}{l}\text { Fouhy et al. } \\
2017^{11}\end{array}$ & $\begin{array}{l}\text { Cystic } \\
\text { Fibrosis }\end{array}$ & $\begin{array}{l}6 \text { patients } \\
6 \mathrm{HI}\end{array}$ & 20-71 years & $\begin{array}{l}\text { NGS } \\
\text { qPCR }^{b}\end{array}$ & $\begin{array}{l}\text { 个Firmicutes } \\
\downarrow \text { Actinobacteria, Bacteroidetes and Proteobacteria } \\
\downarrow \text { Bifidobacterium, B. Longum and Faecalibacterium prausnitzii } \\
\uparrow \text { Enterococcus faecalis, Clostridium and Ruminococcus gnavus }\end{array}$ \\
\hline $\begin{array}{l}\text { Miragoli et al. } \\
2017^{5}\end{array}$ & $\begin{array}{l}\text { Cystic } \\
\text { Fibrosis }\end{array}$ & $\begin{array}{l}30 \text { patients } \\
8 \mathrm{HI}\end{array}$ & $10-22$ years & $\begin{array}{l}\text { PCR-DGGE } \\
\text { qPCR }\end{array}$ & $\begin{array}{l}\downarrow \text { Escherichia coli/Shigella, Blautia spp., Faecalibacterium } \\
\text { prausnitzii, Collinsella aerofaciens, Dialister invisus, Eubacterium } \\
\text { rectale and Bifidobacterium adolescentis, Ruminococcus gnavus, } \\
\text { Bifidobacterium spp., Cl. coccoides group, and Ruminococcaceae } \\
\text { family, Ba. vulgatus and Ba. uniformis } \\
\downarrow \text { Butyrate-producing bacteria and acetogens } \\
\downarrow \text { Prevalence and abundance of Sulfate-Reducing Bacteria }\end{array}$ \\
\hline $\begin{array}{l}\text { Debyser et al. } \\
2016^{12}\end{array}$ & $\begin{array}{l}\text { Cystic } \\
\text { Fibrosis }\end{array}$ & $\begin{array}{l}15 \text { patients } \\
11 \mathrm{HI}\end{array}$ & $1.6-15.6$ years & $\begin{array}{l}\text { Gel electropho- } \\
\text { resis } \\
\text { LC-MS/MS }\end{array}$ & $\begin{array}{l}\downarrow \text { Firmicutes and Actinobacteria } \\
\uparrow \text { Proteobacteria and Bacteroidetes } \\
\downarrow \text { Spectral count of proteins from the genera Faecalibacterium, } \\
\text { Eubacterium, Roseburia and Ruminococcus } \\
\uparrow \text { Spectral count of proteins from the Blautia and Clostridium } \\
\text { species } \\
\uparrow \text { Burkholderiales and Enterobacteriaceae, Clostridiaceae and } \\
\text { genus Clostridium (Clostridium clostridioforme and Clostridium } \\
\text { nexile) }\end{array}$ \\
\hline $\begin{array}{l}\text { Manor et al. } \\
2016^{8}\end{array}$ & $\begin{array}{l}\text { Cystic } \\
\text { Fibrosis }\end{array}$ & $\begin{array}{l}14 \text { patients } \\
12 \mathrm{HI}\end{array}$ & $<3$ years & NGS & $\begin{array}{l}\downarrow \alpha \text {-diversity (Shannon index) } \\
\uparrow \text { Proteobacteria }(E . \text { Coli) and Actinobacteria } \\
\downarrow \text { Firmicutes, Bacteroidetes and Verrucomicrobia } \\
\uparrow \text { Lactobacillales, Veillonella } \\
\downarrow \text { Clostridiales but } \uparrow \text { Cl. difficile }\end{array}$ \\
\hline $\begin{array}{l}\text { Nielsen et al. } \\
2016^{7}\end{array}$ & $\begin{array}{l}\text { Cystic } \\
\text { Fibrosis }\end{array}$ & $\begin{array}{l}23 \text { patients } \\
35 \mathrm{HI}\end{array}$ & $0-18$ years & NGS & $\begin{array}{l}\downarrow \text { Number and diversity } \\
\uparrow \text { Bacteroides, Genera Streptococcus and Falvonifractor } \\
\text { No difference in Clostridium abundance but } \neq \text { tendences with age }\end{array}$ \\
\hline $\begin{array}{l}\text { Duytschaever et } \\
\text { al. } 2013^{15}\end{array}$ & $\begin{array}{l}\text { Cystic } \\
\text { Fibrosis }\end{array}$ & $\begin{array}{l}21 \text { patients } \\
24 \mathrm{HI}\end{array}$ & $\begin{array}{l}8 \text { months }-5,6 \\
\text { years }\end{array}$ & $\begin{array}{l}\text { DGGE } \\
\text { CE } \\
\text { qPCR }\end{array}$ & $\begin{array}{l}\downarrow \text { Bifidobacterium longum, Bifidobacterium catenulatum, Bifido- } \\
\text { bacterium pseudocatenulatum and Bifidobacterium adolescentis } \\
\downarrow \text { Clostridium XIV }\end{array}$ \\
\hline $\begin{array}{l}\text { Hoffman et al. } \\
2013^{19}\end{array}$ & $\begin{array}{l}\text { Cystic } \\
\text { Fibrosis }\end{array}$ & $\begin{array}{l}12 \text { patients } \\
12 \mathrm{HI}\end{array}$ & $\begin{array}{l}15 \text { days }-3,6 \\
\text { years }\end{array}$ & NGS & 个E. coli \\
\hline $\begin{array}{l}\text { Scanlan et al. } \\
2012^{6}\end{array}$ & $\begin{array}{l}\text { Cystic } \\
\text { Fibrosis }\end{array}$ & $\begin{array}{l}4 \text { patients } \\
4 \mathrm{HI}\end{array}$ & $\begin{array}{l}3-72 \\
\text { years }\end{array}$ & PhyloChip ${ }^{f}$ & $\begin{array}{l}\downarrow \text { Taxonomic richness, evenness and diversity } \\
\downarrow \text { Bifidobacterium } s p \text {. } \\
\uparrow \text { inter-individual variation }\end{array}$ \\
\hline $\begin{array}{l}\text { Duytschaever et } \\
\text { al. } 2011^{16}\end{array}$ & $\begin{array}{l}\text { Cystic } \\
\text { Fibrosis }\end{array}$ & $\begin{array}{l}21 \text { patients } \\
24 \mathrm{HI}\end{array}$ & $\begin{array}{l}9 \text { months }-15 \\
\text { years }\end{array}$ & $\begin{array}{l}\text { Bacterial } \\
\text { culture } \\
\text { DGGE }\end{array}$ & $\begin{array}{l}\downarrow \text { Clostridia, Bifidobacterium spp., Veillonella spp., and Bacteroides } \\
\text { and Prevotella spp } \\
\uparrow \text { Enterobacterial counts }\end{array}$ \\
\hline $\begin{array}{l}\text { Ishaq et al. } \\
2018^{17}\end{array}$ & Asthma & $\begin{array}{l}15 \text { patients } \\
5 \mathrm{HI}\end{array}$ & $30-45$ years & $\begin{array}{l}\text { PCR-DGGE } \\
\text { Real-time PCR } \\
\text { CE }\end{array}$ & $\downarrow$ Bifidobacterium, Lactobacillus and Clostridium leptum sub group \\
\hline $\begin{array}{l}\text { Wang et al. } \\
2018^{10}\end{array}$ & Asthma & $\begin{array}{l}36 \text { patients } \\
185 \mathrm{HI}\end{array}$ & & NGS & $\begin{array}{l}\downarrow \text { Faecalibacterium prausnitzii, Sutterella wadsworthensis and } \\
\text { Bacteroides stercoris } \\
\downarrow \text { Microbial richness, evenness and diversity }\end{array}$ \\
\hline $\begin{array}{l}\text { Begley et al. } \\
2018^{13}\end{array}$ & Asthma & $\begin{array}{l}24 \text { patients } \\
8 \mathrm{HI}\end{array}$ & $18-69$ years & NGS & $\begin{array}{l}\downarrow \text { Bacteroidetes/Firmicutes ratio } \\
\downarrow \text { Bacteroides, Enterobacteraceae } \\
\uparrow \text { Bifidobacterium, Lachnospiraceae }\end{array}$ \\
\hline $\begin{array}{l}\text { Okba et al. } \\
2018^{18}\end{array}$ & Asthma & $\begin{array}{l}80 \text { patients } \\
40 \mathrm{HI}\end{array}$ & $18-45$ years & Bacterial Culture & 个 Lactobacillus and E. coli \\
\hline $\begin{array}{l}\text { Hevia et al. } \\
2016^{14}\end{array}$ & Asthma & $\begin{array}{l}21 \text { patients } \\
22 \mathrm{HI}\end{array}$ & $28-50$ years & NGS & $\begin{array}{l}\uparrow \text { Faecalibacterium, Bifidobacterium adolescentis } \\
\downarrow \text { Bifidobacterium longum, Bifidobacterium breve and Bifidobac- } \\
\text { terium bifidum }\end{array}$ \\
\hline
\end{tabular}

${ }^{a}$ Next Generation Sequencing (NGS), ${ }^{b}$ Real-time Polymerase chain reaction (qPCR), 'Denaturing Gradient Gel Electrophoresis (DGGE), ${ }^{d}$ Liquid Chromatography-Mass spectrometry/Mass spectrometry (LC-MS/MS), ${ }^{e}$ Capillary Electrophoresis (CE), ${ }^{f}$ High-density phylogenetic microarray (PhyloChip). 


\section{DISCUSSION}

Cystic fibrosis, asthma, $P H$ and COPD are chronic diseases that affect the lungs and the life quality of patients, with hundreds of millions of people suffering every day from these illnesses. Recently, the role of the GM in the regulation of the immune response has been recognized while studies have showed the existence of GM changes during some pathologies ${ }^{20}$. In this review, we bring information on what currently is known regarding the GM alterations during some $A D$.

Few studies were found that match the inclusion/exclusion criterion of this review. Most of them were about CF. That highlights the need for further studies to detect the existence of GM changes in $A D$ and to determine its importance in the pathology of these diseases. We included only studies without any intervention (probiotics, prebiotics or antibiotics) considering the effect on GM. Only data from human GM was analyzed because of limitations of some experimental models and because animals have a distinct $G M^{21}$. Exclusion criterions such as respiratory and intestinal infection were used to avoid bias in the interpretation of results. The rigor inclusion / exclusion criteria were necessary to provide the most relevant evidence related to the aim. The predominance of studies that evaluate the GM in CF could be reflected by the plenty of articles about lung microbiome for this disease ${ }^{22}$. Although lung microbiome changes have been described to asthma and COPD as well, the volume of data has not been so wide as the one for $\mathrm{CF}^{23-24}$. $\mathrm{PH}$ is a less prevalent disease than is $C F$, asthma and COPD, and this situation can explain the lack of studies about GM changes during the disease.

The development of the more advanced techniques of molecular biology has enabled a more accurate analysis of the GM. These new techniques have not only facilitated the identification of non-cultivated microorganisms ${ }^{25}$ but also improved some experimental limitations such as the low sensitivity and the low reproducibility of the traditional techniques, allowing the identification of a larger number of species and better understanding about the complexity of the intestinal ecosystem ${ }^{26}$. In our review, identification and classification of bacteria from the GM were predominantly performed through culture-independent techniques.

Despide the large number of data indicating the importance of the GM changes during some diseases ${ }^{20}$, there is little knowledge about the existence of GM alterations in $A D$. According to the data, patients with CF showed a reduction in the GM diversity and richness. For asthma, the available data still do not avail a conclusion about the GM changes, even because one of study used stool bacteria culture for the analysis of the composition of GM 18 , which prevents wider conclusions. Microbial diversity decreased with age in CF patients ${ }^{7}$, what is expected in healthy individuals also ${ }^{27}$. In addition, the dysfunction in the Transmembrane Conductance Regulator (CFTR), asso- ciated with the CF treatments, could affect the microbial diversity ${ }^{7}$. CFTR gene variants were related to the shifts in fecal microbiota profiles in CF patients ${ }^{28}$. Individuals with low bacterial richness are characterized as showing more adiposity, insulin resistance and dyslipidaemia and a more inflammatory phenotype ${ }^{29}$. Another alteration detected in the studies that evaluated CF patients concerned the relative abundance of the Firmicutes, Bacteriodetes and Actinobateria phyla. Changes in the Firmicute/Bacteroidete ratio have been described in some pathological conditions ${ }^{30,31}$. Changes in the Firmicutes/Bacteroidetes ratio have been described in infants and adults ${ }^{32}$ and in some pathological conditions such as obesity ${ }^{33-35}$ and IBD ${ }^{30}$. Studies in experimental models of obesity, where mice have been feed with high-fat diet, and in ob/ob mice, have shown that the increase of the Firmicutes/Bacteroidetes ratio has been implicated in the increment of the efficiency of the energy harvest in addition to elevation of the endotoxin levels and induction of the colonic inflammation ${ }^{35,36}$. We suppose that this alteration could be implicated in the increase in the colonic and systemic inflammation. We suppose that this alteration could be implicated in the increase in the colonic and systemic inflammation. The current data do not allow determining whether changes in microbial diversity and richness are consequences or factors that contribute to the development of $A D$, but they show the existence of a lung-gut axis with possible implications for $A D^{37}$.

Similar to CF and other pathologies, asthma patients exhibit GM alterations that characterize dysbiosis: reduction of microbial richness and diversity ${ }^{10}$. Under representation of F. prausnitzii and Roseburia spp. are characteristics of dysbiosis and was detected. These results are similar to those observed in other pathologies 38,39 . F. prausnitzii and Roseburia spp. metabolize dietary components and produce short-chain fatty acids (SCFAs) 40,41. Low amounts of these primary energy sources for the colonocytes may result in decreased intestinal barrier integrity ${ }^{42}$. The SCFAs play a protective role against intestinal inflammation and is likely to be important in both health and in specific disease states ${ }^{42}$. Caco-2 cells treated with F. prausnitzii and its extracellular vesicles produced lower levels of inflammatory and higher levels of the anti-inflammatory cytokines ${ }^{43}$. Roseburia intestinalis suppressed intestinal inflammation by increasing Treg cell numbers and expression of the anti-inflammatory cytokines TSLP, TGF- 6 , and interleukin-10 $(P<0.05)$ in lipopolysaccharide-treated Caco-2 cells ${ }^{44}$. The decrease of F. prausnitzii and Roseburia spp. from GM might contribute to an increase of pulmonary inflammation during CF.

Bifidobacteria, beneficial bacteria for the intestine, are also altered in CF patients and asthma. This has been described for other pathological conditions ${ }^{45}$. Some studies detected a reduction of bifidobacteria or lactobacilli ${ }^{17}$ and others showed an increase of these genus in asthma patient ${ }^{13,18}$. These bacteria have been used in the treatement of some pathologies because of their probiotic 
effect, and some authors have discussed the beneficial effect of this supplementation for the asthma patients ${ }^{46}$. The supplementation with a mixture of $L$. acidophilus, $L$. bulgaricus, B. bifidum, S. thermophilus (Bio-plus, Supherb, Israel) reduced pulmonary exacerbations in patients with $C F^{47}$. In children with $C F$, the administration of $L$. rhamnosus GG (LGG) restored the composition of the GM, reduced the intestinal inflammation and contributed to its beneficial clinical effects ${ }^{48}$. Also, the supplementation with probiotics used commercially contains $10^{9} \mathrm{CFU}$ bacteria: L. casei, L. rhamnosus, S. thermophilus, B. breve, L. acidophilus, $B$. infantis and $L$. bulgaricus improve quality of life and pulmonary exacerbation ${ }^{49}$. These data suggest that supplementation with the probiotics improved the respiratory function.

Data also show an alteration in the abundance of $E$. coli in patients with CF and asthma. The expansion of $E$. coli in the CF gut may be due to the decreased presence of antimicrobial SCFAs, the increased oxygenation of GI mucosal surfaces as a result of inflammation and the higher availability of glycerol from fat malabsorption ${ }^{50}$. E. coli levels were increase in homozygous-F508del, the most common CFTR mutation, and in severe CF patients, while beneficial species (Faecalibacterium prausnitzii, Bifidobacterium spp., and Eubacterium limosum) were reduced ${ }^{28}$. Similar results found to those were present investigation in a study involving children with CF in the use of antibiotic therapy ${ }^{51}$. The elevation of the E. coli levels of asthma patients was analyzed by bacterial culture ${ }^{18}$ using different methodologies, which could explain in part the opposite data obtained by groups ${ }^{52}$.

The FEV ${ }_{1}$ is a marker of the lung function and has been used to monitor the evolution of the ADs. Cystic Fibrosis patients with severe lung dysfunction (FEV ${ }_{1} \leq 40 \%$ ) had reduced $\alpha$-diversity when compared with those with mild or moderate lung dysfunction ${ }^{9}$. However, no correlation was found in the fecal microbiota with the FEV. The analysis of the relation of bacteria groups from GM with the function parameters may improve the understanding about the impact of the intestinal bacteria in the development and outcome of the disease.

The current data suggest the presence of the intestinal dysbiosis in individuals with CF and asthma. However, it is not possible to affirm that there is dysbiosis in other $A D$, due to the insufficient number of publications. The main alterations in the GM of CF and asthma patients are similar to the GM changes observed in other pathologic conditions such as alterations in Firmicutes and Bacteroidetes phyla, in the microbial diversity and richness and in the levels of beneficial bacteria as bifidobacteria. This panorama reveals the necessity of more studies that could bring information about the GM changes and the relevance of dysbiosis for the $A D$. This information could show similarities of $G M$ changes in the distinct $A D$ and bring new possibilities of studies or therapies for the patients.

\section{Support statement}

LMG de Oliveira is funded by a fellowship from the Fundação de Amparo à Pesquisa do Estado da Bahia.

\section{REFERENCES}

1. NOVERR, M. C.; HUFFNAGLE, G. B. Does the microbiota regulate immune responses outside the gut? Trends Microbiol., Cambridge, v. 12, n. 12, p.562-568, Dez. 2004.

2. ICHINOHE, T. et al. Microbiota regulates immune defense against respiratory tract influenza A virus infection. Proc. Natl. Acad. Sci., U.S. A., Washington, v. 108, n. 13, p.5354-5359, 14 Mar. 2011.

3. MATEER, S. W. et al. Potential mechanisms regulating pulmonary pathology in inflammatory bowel disease. J. Leukoc. Biol., New York, v. 98, n. 5, p.727-737, 25 Ago. 2015.

4. ABREU, M. T. Toll-like receptor signalling in the intestinal epithelium: how bacterial recognition shapes intestinal function. Nat. Rev. Immunol., London, v. 10, n. 2, p.131-144, Feb. 2010.

5. MIRAGOLI, F. et al. Impact of cystic fibrosis disease on archaea and bacteria composition of gut microbiota. FEMS Microbiol. Ecol., Oxford, v. 93, n. 2, p.93-95, 2 nov. 2016.

6. SCANLAN, P. D. et al. Gut dysbiosis in cystic fibrosis. J. Cyst. Fibros., Amsterdam, v. 11, n. 5, p. 454-455, 2012

7. NIELSEN, S. et al. Disrupted progression of the intestinal microbiota with age in children with cystic fibrosis. Scientific Reports, London, v. 6, n. 1, p.24857-24867, 4 May 2016.

8. MANOR, O. et al. Metagenomic evidence for taxonomic dysbiosis and functional imbalance in the gastrointestinal tracts of children with cystic fibrosis. Scientific Reports, London, v. 6, n. 1, p.22493-22502, Mar. 2016.

9. BURKE, D. G. et al. The altered gut microbiota in adults with cystic fibrosis. BMC Microbiol., London, v. 17, n. 1, p.58-68, 9 Mar. 2017.

10. WANG, Q. et al. A metagenome-wide association study of gut microbiota in asthma in UK adults. BMC Microbiol., London, v. 18, n. 1, p.114-120, 12 Sept. 2018

11. FOUHY, F. et al. A pilot study demonstrating the altered gut microbiota functionality in stable adults with Cystic Fibrosis. Scientific Reports, London, v. 7, n. 1, p.6685-6696, 27 July 2017.

12. DEBYSER, G. et al. Faecal proteomics: A tool to investigate dysbiosis and inflammation in patients with cystic fibrosis. J. Cyst. Fibros., Amsterdam, v. 15, n. 2, p.242-250, Mar. 2016.

13. BEGLEY, L. et al. Gut microbiota relationships to lung function and adult asthma phenotype: a pilot study. Bmj Open Respiratory Research, London, v. 5, n. 1, p.000324-000330, Sept. 2018.

14. HEVIA, A. et al. Allergic patients with long-term asthma display low levels of bifidobacterium adolescentis. PLOS One, San Francisco, v. 11, n. 2, p.0147809-0147820, 3 Feb. 2016

15. DUYTSCHAEVER, G. et al. Dysbiosis of bifidobacteria and Clostridium cluster XIVa in the cystic fibrosis fecal microbiota. J. Cyst. Fibros., Amsterdam, v. 12, n. 3, p.206-215, May 2013.

16. DUYTSCHAEVER, G. et al. Cross-Sectional and longitudinal comparisons of the predominant fecal microbiota compositions of a group of pediatric patients with cystic fibrosis and their healthy siblings. Applied And Environmental Microbiology, Washington, v. 77, n. 22, p.80158024, 16 Sept. 2011.

17. ISHAQ, H. M. et al. Gut Microbe analysis between asthma patients 
and healthy Volunteers in Shaanxi Province, Xian, China. Pakistan Journal Of Zoology, Pakistan, v. 50, n. 1, p.165-173, Jan. 2018.

18. OKBA, A. M. et al. Fecal microbiota profile in atopic asthmatic adult patients. Eur. Ann. Allergy Clin. Immunol., Paris, v. 50, n. 03, p.117-124, Feb. 2018.

19. HOFFMAN, L. R. et al. Escherichia coli dysbiosis correlates with gastrointestinal dysfunction in children with cystic fibrosis. Clin. Infect. Dis., Chicago, v. 58, n. 3, p.396-399, 30 out. 2013

20. LEVY, M. et al. Dysbiosis and the immune system. Nat. Rev. Immunol., London, v. 17, n. 4, p.219-232, 6 Mar. 2017.

21. ERICSSON, A. C. "The use of non-rodent model species in microbiota studies", Laboratory Animals, London, v. 53, n. 3, p. 259-270, Jun. 2019.

22. ACOSTA, N. et al. Sputum microbiota is predictive of long-term clinical outcomes in young adults with cystic fibrosis. Thorax, London, v. 73, n. 11, p.1016-1025, 22 Ago. 2018.

23. DIAO, W. et al. Symptom-related sputum microbiota in stable chronic obstructive pulmonary disease. Int. J. Chronic Obst. Pulm. Dis., Auckland, v. 13, p.2289-2299, July 2018.

24. MATHIEU, E. et al. Paradigms of lung microbiota functions in health and disease, particularly, in Asthma. Front. Physiol., Lausanne, v. 9, p.1168-1178, 21 Ago. 2018.

25. FRAHER, M. H. et al. Techniques used to characterize the gut microbiota: a guide for the clinician. Nat. Rev. Gastroenterol. Hepatol., London, v. 9, n. 6, p.312-322, 27 Mar. 2012.

26. KEMPERMAN, R. A. et al. Novel approaches for analysing gut microbes and dietary polyphenols: challenges and opportunities. Microbiology, London, v. 156, n.11, p.3224-3231, 19 Ago. 2010.

27. CLAESSON, M. J. et al. Gut microbiota composition correlates with diet and health in the elderly. Nature, London, v. 488, n. 7410, p.178184, 13 July 2012.

28. SCHIPPA, S. et al. Cystic Fibrosis Transmembrane Conductance Regulator (CFTR) allelic variants relate to shifts in faecal microbiota of cystic fibrosis patients. PLOS One, San Francisco, v. 8, n. 4, p.6117661187, 17 Abr. 2013.

29. CHATELIER, E. L. et al. Richness of human gut microbiome correlates with metabolic markers. Nature, London, v. 500, n. 7464, p.541-546, Ago. 2013.

30. JEFFERY, I. B. et al. An irritable bowel syndrome subtype defined by species-specific alterations in faecal microbiota. Gut, London, v. 61, n. 7, p.997-1006, Dec. 2012.

31. MOUZAKI, M. et al. Intestinal microbiota in patients with nonalcoholic fatty liver disease. Hepatology, Baltimore, v. 58, n. 1, p.120-127, 14 May 2013.

32. MARIAT, D., FIRMESSE, O., LEVENEZ, F., et al. "The firmicutes/ bacteroidetes ratio of the human microbiota changes with age", BMC Microbiology, London, v. 9, p. 1-6, Jun. 2009.

33. BERVOETS, L. et al. Differences in gut microbiota composition between obese and lean children: a cross-sectional study. Gut pathogens, London, v. 5, n. 1, p. 10, 2013.

34. KOLIADA, A. et al. "Association between body mass index and Firmicutes/Bacteroidetes ratio in an adult Ukrainian population", BMC Microbiology, London, v. 17, n. 1, p. 4-9, May. 2017.

35. MURPHY, E. F. et al. "Composition and energy harvesting capacity of the gut microbiota: relationship to diet, obesity and time in mouse models", Gut, London, v. 59, n. 12, p. 1635-1642, Dec. 2010.
36. KIM, K. A. et al. "High Fat Diet-Induced Gut Microbiota Exacerbates Inflammation and Obesity in Mice via the TLR4 Signaling Pathway", PLoS ONE, San Francisco, v. 7, n. 10, Oct. 2012.

37. ZHANG, D. et al. "The cross-talk between gut microbiota and lungs in common lung diseases", Frontiers in microbiology, [s.I], v. 11, n. , p. 1-14, Feb. 2020.

38. MACHIELS, K. et al. A decrease of the butyrate-producing species Roseburia hominis and Faecalibacterium prausnitzii defines dysbiosis in patients with ulcerative colitis. Gut, London, v. 63, n. 8, p.1275-1283, 10 Sept. 2014.

39. JIANG, S. et al. A reduction in the butyrate producing species Roseburia spp. and Faecalibacterium prausnitzii is associated with chronic kidney disease progression. Antonie Leeuwenhoek, Wageningen, v. 109, n. 10, p.1389-1396, 18 July 2016.

40. NEYRINCK, A. M. et al. Prebiotic Effects of wheat arabinoxylan related to the increase in bifidobacteria, roseburia and bacteroides/ prevotella in diet-induced obese mice. PLOS One, San Francisco, v. 6, n. 6, p.20944-20955, 9 June. 2011.

41. RIOS-COVIAN, D. et al. Enhanced butyrate formation by cross-feeding between Faecalibacterium prausnitzii and Bifidobacterium adolescentis. FEMS Microbiol. Lett., England, v. 362, n. 21, p.176-182, 28 Sept. 2015.

42. BENUS, R. F. J. et al. Association between Faecalibacterium prausnitzii and dietary fibre in colonic fermentation in healthy human subjects. $\mathrm{Br}$ J. Nutr., London, v. 104, n. 5, p.693-700, 29 Mar. 2010.

43. RABIEI, N. et al. "Induction effects of Faecalibacterium prausnitzii and its extracellular vesicles on toll-like receptor signaling pathway gene expression and cytokine level in human intestinal epithelial cells", Cytokine, San Diego, v. 121, n. May, p. 154718, 2019.

44. SHEN, Z. et al. "Insights into Roseburia intestinalis which alleviates experimental colitis pathology by inducing anti-inflammatory responses", J. Gastroenterol. Hepatol., Australia, v. 33, n. 10, p. 1751-1760, Mar. 2018.

45. KERCKHOFFS, A. P. M. et al. Lower Bifidobacteria counts in both duodenal mucosa-associated and fecal microbiota in irritable bowel syndrome patients. World j. gastroenterol., Beijing, v. 15, n. 23, p. 2887, 2009.

46. MENNINI, M. et al. Probiotics in asthma and allergy prevention. Front. Pediatr., Lausanne, v. 5, p. 165, 2017.

47. WEISS, B. et al. Probiotic supplementation affects pulmonary exacerbations in patients with cystic fibrosis: a pilot study. Pediatr. pulmonol., Philadelphia, v. 45, n. 6, p. 536-540, 2010.

48. BRUZZESE, E. et al. Disrupted intestinal microbiota and intestinal inflammation in children with cystic fibrosis and its restoration with lactobacillus GG: a randomised clinical trial. PLOS One, San Francisco, v. 9, n. 2, p.87796-87807, 19 Feb. 2014.

49. JAFARI, S. A. et al. Effects of probiotics on quality of life in children with cystic fibrosis; a randomized controlled trial. Iranian journal of pediatrics, Tehran, v. 23, n. 6, p. 669, 2013.

50. MATAMOUROS, S. et al. Adaptation of commensal proliferating Escherichia coli to the intestinal tract of young children with cystic fibrosis. Proc. Natl. Acad. Sci., U.S. A., Washington, v. 115, n. 7, p.16051610, 29 Jan. 2018.

51. DE FREITAS, M. B. et al. "Altered intestinal microbiota composition, antibiotic therapy and intestinal inflammation in children and adolescents with cystic fibrosis", PLoS ONE, San Francisco, v. 13, n. 6, p. 1-14, Jun. 2018. 
52. PANEK, M. et al. Methodology challenges in studying human gut microbiota - effects of collection, storage, DNA extraction and next generation sequencing technologies. Scientific Reports, London, v. 8, n. 1, p.5143-5156, 23 Mar. 2018.

Submetido em: 03/11/2019

Aceito em: 01/04/2020 